\title{
PEMBUATAN PELET IKAN APUNG BERBAHAN LOKAL DENGAN TEKNOLOGI STEAMER DI DESA DAHAN REJO, KECAMATAN KEBOMAS, GRESIK
}

\author{
Choirul Anam ${ }^{1 *}$, Miftahul Huda ${ }^{2}$, Ana Amiroh ${ }^{3}$ \\ 1,2,3Universitas Islam Darul Ulum \\ *email : choirulanam@unisda.ac.id
}

\begin{abstract}
Dahan Rejo Village, Kebomas District is one of the centers of fish farming centers in Gresik Regency. The obstacle faced by pond farmers is the high price of feed, which increases the cost of production and capital. Farmers have not yet used alternative feed and are still dependent on factory-made pellets. The alternative solution that can be done is to make pellets from local materials such as tofu pellets and corn with steamer technology. The aim of this program is to empower the people of Dahan Rejo Village to make floating fish feed from local materials. The methods used are program preparation, product making and proximate analysis, making tutorial videos and guidebooks, socializing and training, mentoring, monitoring, and evaluating. The result of this community empowerment program is that farmer groups have the potential to develop floating fish pellets. Proximate analysis of floating fish pellets showed protein content of $31.6 \%$, $6.8 \%$ fat, $4.2 \%$ reducing sugar, $4.4 \%$ crude fiber, and Ca minerals $0.3 \%$. Tutorial videos and guidebooks for making floating fish pellets are good and suitable for use by the community. Farmers can make pellets from local raw materials independently with the percentage of material achievement being $70 \%$ of the total number of group members. The accompanying results show that the obstacles faced by fish pond farmers are weather, supporting raw materials, and marketing. The monitoring and evaluation results show that pond farmers in Dahan Rejo Village are committed to developing floating fish pellets from local raw materials as an effort to sustain the program.
\end{abstract}

Key words: pellets, local materials, steamer

\section{PENDAHULUAN}

Salah satu upaya peningkatan kualitas sumberdaya manusia dan sumber ekonomi baru di Kabupaten Gresik dilakukan dengan jalan meningkatkan peran sektor perikanan dalam pengentasan kemiskinan dan perluasan lapangan pekerjaan (Aryani, F. 1994). Kebijakan ini diwujudkan dengan pembentukan Kelompok-kelompok Pembudidaya Ikan di beberapa daerah yang menjadi sentra budidaya perikanan air tawar.

Kelompok pembudidaya ikan di Desa Dahanrejo, Kecamatan Kebomas, Gresik merupakan salah satu pembudidaya ikan yang dibentuk dalam upaya pembukaan lapangan kerja dan peningkatan sumber ekonomi baru bagi masyarakat di Desa Dahanrejo. Kelompok pembudidaya 
ISSN : $2620-4665$ (print)

ISSN : 2620 - 4673 (online)

Website : http://jurnal.untan.ac.id/index.php/JPLP2KM

ikan bandeng, lele Dahanrejo didirikan pada tahun 2012, dengan komoditas utama berupa usaha pembudidaya ikan bandeng dan lele.

Pola budidaya yang diterapkan di kelompok pembudidaya ikan Dahanrejo sudah tidak lagi mengandalkan pakan alami, melainkan pakan buatan (pakan pabrik). Pakan merupakan komponen utama dalam budidaya perikanan, dengan memberikan porsi terbesar dalam struktur komponen biaya. Biaya pakan mencapai $75 \%$ dari total biaya yang harus dikeluarkan oleh pembudidaya ikan dalam satu siklus produksi. Padahal, dalam satu kali siklus produksi budidaya ikan di Desa Dahanrejo, pembudidaya ikan bisa menghabiskan pakan buatan (pakan pabrik) mencapai sekitar $500 \mathrm{~kg}$.

Ketersediaan pakan untuk kegiatan budidaya perikanan seringkali belum sepenuhnya memenuhi kriteria lima tepat, yaitu a) tepat mutu, b) tepat jumlah, c) tepat tempat, d) tepat jenis dan e) tepat harga. Secara mutu, pakan jenis pelet yang diproduksi oleh pabrik sebagian besar dinilai sudah mengandung nutrisi sesuai persyaratan yang tercantum dalam SNI. Pengakuan akan hal ini dibuktikan dalam bentuk terdaftarnya pakan produk pabrikan yang beredar di pasaran. Seringkali industri pengolahan pelet ikan skala kecil kebingungan untuk memenuhi kebutuhan sesuai SNI /pasar karena harus bersaing dengan produk pabrikan yang sudah unggul, sehingga tidak sedikit industri pembuatan pelet ini yang gulung tikar.

Kenaikan harga pakan buatan (pakan pabrik) pada akhir-akhir ini telah menciptakan permasalahan baru bagi pembudidaya ikan di Desa Dahanrejo. Kenaikan harga pakan buatan (pakan pabrik) telah menyebabkan margin keuntungan pembudidaya ikan di Desa Dahanrejo semakin kecil. Permasalahan ini coba diselesaikan oleh anggota kelompok dengan cara memproduksi pakan sendiri. Pakan yang diproduksi oleh kelompok pembudidaya ikan di Desa Dahanrejo masih menggunakan peralatan sederhana dan dengan formulasi bahan penyusun pakan yang masih mengandalkan pengalaman pembudidaya.

Penggunaan pakan produksi sendiri ternyata masih belum menyelesaikan permasalahan. Hal ini dikarenakan pakan yang dihasilkan sangat mudah untuk pecah dan larut dalam air. Penggunaan pakan seperti ini dalam proses budidaya menyebabkan penurunan kualitas air kolam atau tambak menjadi lebih cepat karena sebagian besar pakan yang diberikan akan tenggelam sebelum dimakan oleh ikan. Inovasi teknologi tepat guna yang dapat menghasilkan pakan dengan tekstur yang baik dan memiliki daya apung yang cukup untuk budidaya ikan serta memiliki kandungan nutrisi yang tinggi diharapkan dapat menyelesaikan permasalahan 
pembudidaya ikan di Desa Dahanrejo, Kecamatan Kebomas, Kabupaten Gresik. Pak Nuharto merupakan pemilik pabrik pelet ikan apung yang beralamatkan di Desa tersebut. Meskipun sudah berjalan kurang lebih 3 tahun namun Industri pembuatan pelet yang dimilikinya masih tergolong berskala sedang. Sementara hasil produksinya mencapai $700 \mathrm{kwintal} / \mathrm{bulan}$. Beberapa masalah yang dihadapi adalah kualitas produksinya masih kurang maksimal baik dari segi kwalitas maupun kwantitas. Hal ini desebabkan karena sarana dan prasarana yang digunakan masih sederhana padahal untuk bisa bersaing dengan produk pabrikan dibutuhkan sentuhan teknologi baru untuk meningkatkan nilai tambah produk.

Disamping itu beberapa persoalan yang dihadapi mitra adalah : a) Pelet yang dihasilkan kurang padat sehingga mudah larut di air, b) Kurang tahan lama dalam pinyimpanan, c) Daya apung yang relatif sebentar/cepat tenggelam (3 menit), d) Proses mixing/pengadukan masih

manual sehingga proses pencapuran kurang maksimal dan butuh waktu lama, e) Masih adanya kandungan bakteri, dan f) Teknologi yang digunakan sangat sederhana dan manual. Untuk mengatasi persoalan tersebut diatas perlu adanya sentuhan dan tambahan teknologi inovasi sehingga produk pelet yang dihasilkan dapat bertambah dari segi kwalitas maupun kwantitas.

\section{METODE PELAKSANAAN}

\subsection{WAKTU DAN TEMPAT}

Kegiatan ini dilakukan selama 4 bulan mulai bulan Juli sampai dengan Oktober 2018 di Desa Dahan Rejo, Kecamatan Kebomas, Kabupaten Gresik, Jawa Timur

\subsection{ALAT DAN BAHAN}

Alat yang digunakan pada program ini adalah blender, baskom, pengaduk, timbangan, saringan, ember, mesin penggiling, mesin pencetak pelet, terpal, dan mesin press. Bahan yang digunakan adalah ampas tahu, tepung ikan/ebi, tepung jagung, tepung tapioka, probiotik, dan minyak ikan.

\subsection{PROSEDUR KERJA PEMBUATAN PELET APUNG}

Prosedur kerja pembuatan pelet ampas tahu dan probiotik adalah: 1) Mempersiapkan alat dan bahan; 2) Menggiling bahan kasar menjadi bentuk tepung yang halus; 3) Mengayak bahanbahan tepung agar teksturnya halus; 4) Mencampur semua bahan sampai tercampur rata; 5) Membiarkan campuran agak mengering; 6) Menggiling dan mencetak pelet; dan 7) Mengeringkan pelet. 
ISSN : $2620-4665$ (print)

ISSN : 2620 - 4673 (online)

Website : http://jurnal.untan.ac.id/index.php/JPLP2KM

\subsection{BENTUK KEGIATAN}

Bentuk kegiatan secara keseluruhan mencakup: 1) Persiapan program; 2) Pembuatan produk dan analisis proksimat pelet ikan apung; 3) Pembuatan video tutorial dan buku panduan pembuatan pelet ikan apung; 4) Sosialisasi dan pelatihan pembuatan pelet ikan apung; 5) Pendampingan; dan 6) Monitoring dan evaluasi.

\subsection{METODE PENGUMPULAN DAN ANALISIS DATA}

Metode pengumpulan data pada program ini adalah dengan menggunakan tes uraian singkat terkait materi pembuatan pakan ikan apung, wawancara dan lembar observasi. Analisis data menggunakan deskriptif kualitatif.

\section{HASIL DAN PEMBAHASAN}

Program pemberdayaan masyarakat dalam memproduksi pellet ikan apung berbahan lokal di Desa Dahan Rejo, Kecamatan Kebomas, Kabupaten Gresik. ini dilakukan secara terstruktur dan melibatkan masyarakat secara langsung. Kegiatan ini dilaksanakan pada kelompok petani tambak sejumlah 40 orang.

\subsection{Pelaksanaan Program Pemberdayaan Masyarakat}

Kegiatan pemberdayaan masyarakat ini dimulai dari persiapan program yang meliputi survei lokasi, keadaan, dan temuan secara real di lapangan. Lokasi yang menjadi sasaran adalah petani tambak di Desa Dahan Reja, Kecamatan Kebomas, Kabupaten Gresik. Survei dilakukan dengan mengamati keadaan petambak ikan bandeng, udang vanami dan wawancara dengan petani tambak, ketua kelompok, warga desa, dan pemerintah Desa Dahan Rejo. Hasil survei menunjukkan bahwa kendala yang dihadapi oleh petani tambak antara lain 1) Mahalnya harga pakan lele; 2) Peralatan sederhana; 3) Cuaca yang tidak menentu; 4) Kurangnya pasokan benih unggul; dan 5) Minimnya permodalan. Berdasarkan lima kendala umum tersebut, maka dipilih prioritas pemecahan masalah pada poin 1 dan 2, yaitu pemenuhan pakan dan bantuan peralatan moderen. Alternatif yang digunakan adalah pembuatan pelet ikan apung dari produk lokal. Produk lokal yang dapat dieksplorasi dari Desa Dahan Rejo adalah ampas tahu, tepung jagung, tepung ikan, sehingga bahan tersebut dipilih sebagai bahan utama pembuatan pelet ikan apung.

Tahap selanjutnya adalah persiapan instrumen monitoring dan evaluasi, yaitu soal tes pengetahuan masyarakat, lembar observasi keterampilan (skil), lembar observasi kegiatan, dan potensi keberlanjutan. Selanjutnya, perijinan dan pembahasan program bersama masyarakat dan pemerintah Desa Dahan Rejo, Kecamatan Kebomas, Kabupaten Gresik. 


\subsection{Pembuatan Produk dan Analisis Proksimat}

Pembuatan produk dalam skala kecil dilakukan di Laboratorium Pertanian Terpadu, Universitas Islam Darul 'Ulum Lamongan. Alat dan bahan disiapkan dengan seksama, kemudian dilakukan pembuatan pelet ikan apung dengan teknologi steamer sesuai dengan prosedur yang telah ditetapkan. Pembuatan produk skala kecil ini digunakan sebagai bahan yang akan diuji kadar proksimat yang meliputi kadar protein, lemak, gula reduksi, serat, dan mineral. Produk pelet ikan apung terlihat pada Gambar 1.

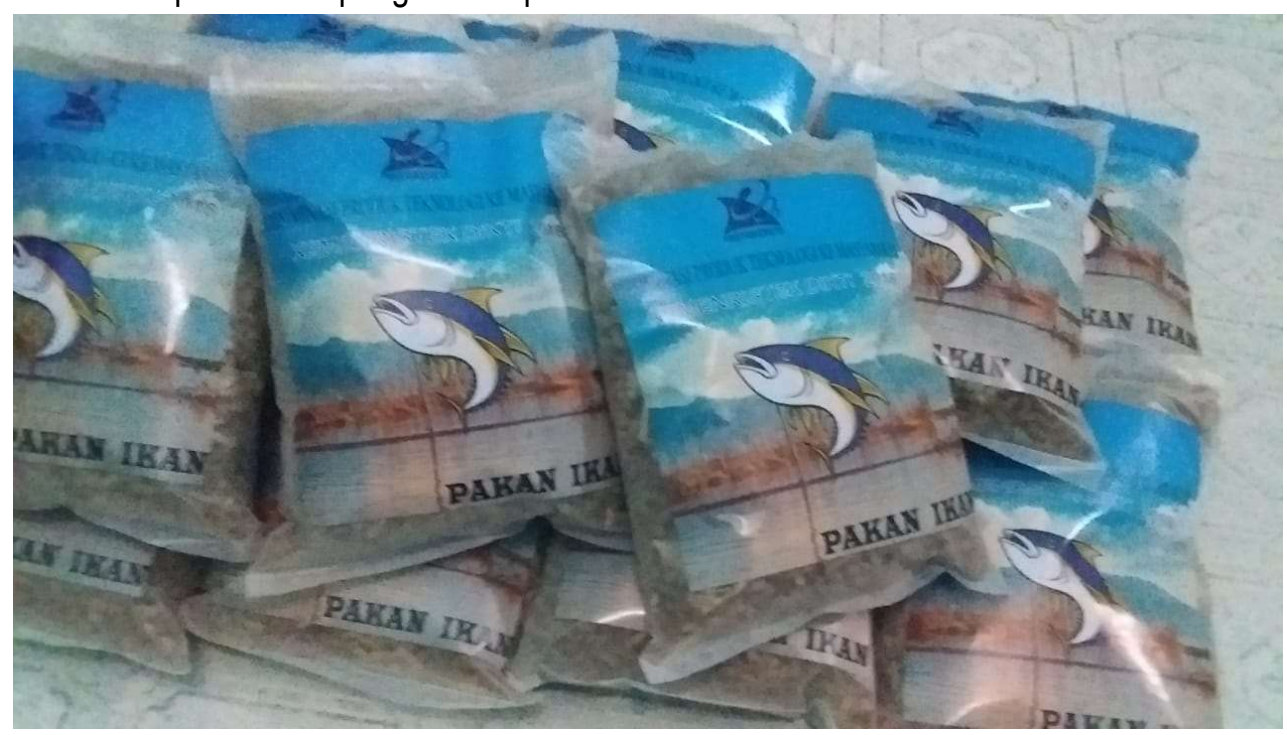

Gambar 1. Produk pelet ikan apung

Analisis laboratorium menunjukkan bahwa pelet ikan apung dari bahan lokal mengandung kadar protein sebesar 31,6\%, lemak 6,8 \%, gula reduksi $4,2 \%$, serat kasar 4,4 $\%$, dan mineral $\mathrm{Ca} 0,3 \%$. Analisis proksimat pelet ikan ini menunjukkan bahwa kadar ini memenuhi salah satu kriteria standar makanan ikan. Nasution (2006) menyampaikan bahwa kadar protein yang baik untuk ikan adalah $30 \%-36 \%$. Sedangkan Mujiman (2003) menyampaikan bahwa kebutuhan lemak ikan air tawar berkisar $4 \%-18 \%$. Hasil analisis ini menunjukkan bahwa produk pelet ikan apung dapat digunakan untuk pertumbuhan ikan lele, dan berbagai jenis ikan lainnya seperti bandeng, nila, dan gurami (Lestari et al. 2013; Hanif et al. 2014; Boer et al. 2014).

\subsection{Pembuatan Video Tutorial dan Buku Panduan Pembuatan Pelet Ikan Apung}

Selain produk berupa pelet, terdapat juga produk berupa video tutorial dan buku panduan pembuatan pelet ikan apung yang dapat membantu dan memudahkan masyarakat dalam memahami dan membuat pelet alternatif. Video tutorial ini dibuat di Laboratorium Terpadu Universitas Islam Darul 'Ulum Lamongan dengan menggambarkan alat, bahan, dan prosedur kerja pembuatan pelet ikan apung berbahan baku lokan dengan teknologi steamer. Video tutorial ini merupakan media pendukung yang mendorong adanya hubungan interaktif 
ISSN : $2620-4665$ (print)

ISSN : 2620 - 4673 (online)

Website : http://jurnal.untan.ac.id/index.php/JPLP2KM

masyarakat selama pelatihan berlangsung. Sebelum digunakan di masyarakat, video tutorial ini juga diuji kelayakannya oleh tim ahli IT di Universitas Islam Darul 'Ulum Lamongan, berbagai saran dan masukan dilakukan sebagai upaya perbaikan. Selain itu, juga divalidasi oleh tim dosen media interaktif. Aspek yang menjadi penilaian adalah kualitas video, potensi interaksi, bahasa, dan tampilan. Hasil validasi menunjukkan bahwa penilaian dari tim dosen media interaktif mendapatkan kriteria baik untuk kualitas video, sangat baik untuk potensi interaksi, dan baik dari segi bahasa dan tampilan. Maka dapat disimpulkan bahwa media video tutorial pembuatan pelet ikan ikan apung ini layak dan dapat digunakan di masyarakat. Media pendukung lainnya adalah buku panduan pembuatan pelet ikan apung. Buku ini berisi tentang potensi bahan baku lokal dan pembuatan pelet ikan apung, dan segala sesuatu yang berkaitan dengan pakan ikan. Buku panduan ini nantinya akan digunakan sebagai media untuk meningkatkan pengetahuan masyarakat khususnya petani tambak ikan dalam memahami cara pembuatan pakan ikan alternatif berupa pelet ikan apung. Sebelum disebarluaskan di masyarakat, buku panduan ini juga telah divalidasi oleh tim ahli buku ajar Universitas Islam Darul 'Ulum Lamongan. Validasi meliputi aspek sistematika, tata bahasa, isi, gambar, dan layout. Penilaian dari tim validasi bahwa buku panduan pembuatan pelet ikan apung berbahan baku lokal layak untuk digunakan di masyarakat.

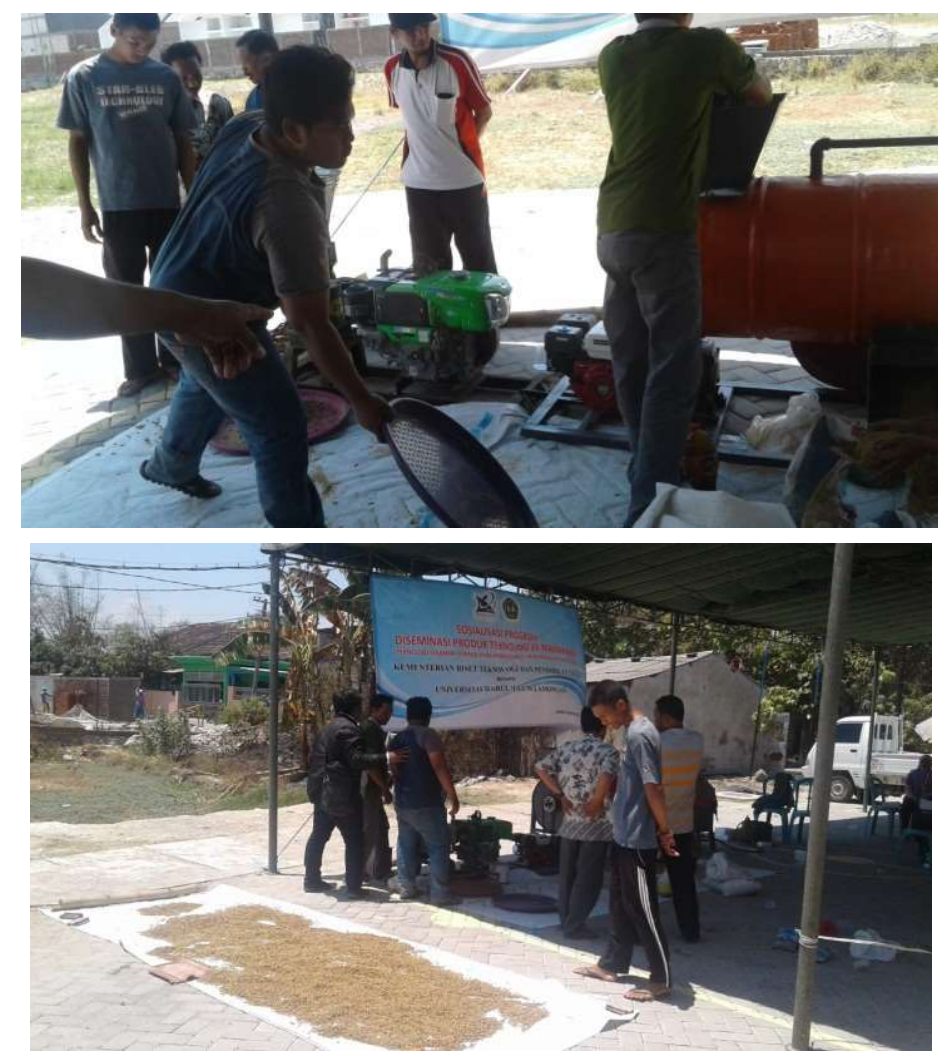

Gambar 3 Proses pembuatan produk pelet ikan apung dengan steamer. 


\subsection{Sosialisasi dan Pelatihan Pembuatan Pelet lkan Apung}

Pelatihan pembuatan pelet ikan apung (Gambar 3) dilakukan sebanyak 2 kali di balai Desa Dahan Rejo. Pelatihan pertama adalah pelatihan terkait pembuatan pakan ternak alternatif dari bahan-bahan lokal khususnya ampas tahu, tepung jagung. Ampas tahu dipilih karena tersedia dalam jumlah yang besar di Desa dan belum sepenuhnya dimanfaatkan. Pelatihan kedua berisi tentang pengemasan, pemasaran, dan manajemen usaha. Kedua pelatihan ini dilakukan dengan metode ceramah, diskusi, dan praktik langsung dengan pendekatan partisipatif.

Hasil dari pelatihan pertama adalah kelompok Petani tambak Desa Dahan Rejo sangat antusias dan tertarik dengan program ini. Program ini dirasa sangat relevan di tengah mahalnya harga pelet ikan buatan pabrik. Motivasi untuk membuat pakan ikan terapung alternatif sebenarnya sudah ada sejak lama, namun karena belum adanya dukungan peralatan dan inisiasi dari petani tambak maka upaya ini belum berjalan optimal dan petani tambak tetap menggunakan pelet produksi pabrik. Proses pelatihan pembuatan pelet ini meliputi penyampaian materi, penyampaian video tutorial dan buku panduan, persiapan alat dan bahan, membuat campuran pelet, menggiling, dan mengeringkan pelet. Target dari pelatihan ini adalah petani tambak mampu membuat pelet ikan dari ampas tahu dan bahan lokal lainnya baik secara teori maupun praktik. Aspek ketercapaian taget dinilai dengan menggunakan instrumen. Instrumen berupa soal tes digunakan untuk mengukur tingkat keterserapan materi, sedangkan lembar observasi digunakan untuk melihat keterampilan dalam mempraktikkan cara pembuatan pelet ikan dari bahan lokal seperti ampas tahu dan tepung jagung. Hasil ketercapaian materi dari 20 orang sasaran dapat dilihat pada Gambar 4.

Gambar 4 menunjukkan bahwa mayarakat peserta pelatihan yang tercapai dengan nilai di atas 70 adalah sebanyak 14 orang dengan persentase $70 \%$. Hal ini karena pada saat penyampaian materi disampaikan dengan jelas, bahasa yang sederhana, menggunakan media pendukung berupa video tutorial, dan buku panduan. Penyampaian yang baik akan membawa ketercapaian materi yang baik, efektif dan efisien. Masyarakat yang belum tercapai kemampuan kognitif dan pengetahuan tentang cara membuat pelet ikan adalah sebanyak 6 orang dengan persentase $30 \%$. Ketidaktercapaian ini dikarenakan tergolong usia non produktif sehingga kurang antusias dengan kegiatan yang bersifat teoritis. Berdasarkan hasil pencapaian tersebut, maka secara umum dapat dikatakan bahwa pelatihan ini dapat meningkatkan pengetahuan masyarakat tentang pembuatan pelet ikan apung dari bahan lokal.

Berdasarkan data dari lembar observasi menunjukkan bahwa $80 \%$ masyarakat mampu membuat pelet ikan dari bahan lokal (Gambar 5). Kemampuan ini menunjukkan keterserapan materi pelatihan dapat diaplikasikan dengan baik oleh masyarakat. 
ISSN : $2620-4665$ (print)

ISSN : $2620-4673$ (online)

Website : http://jurnal.untan.ac.id/index.php/JPLP2KM

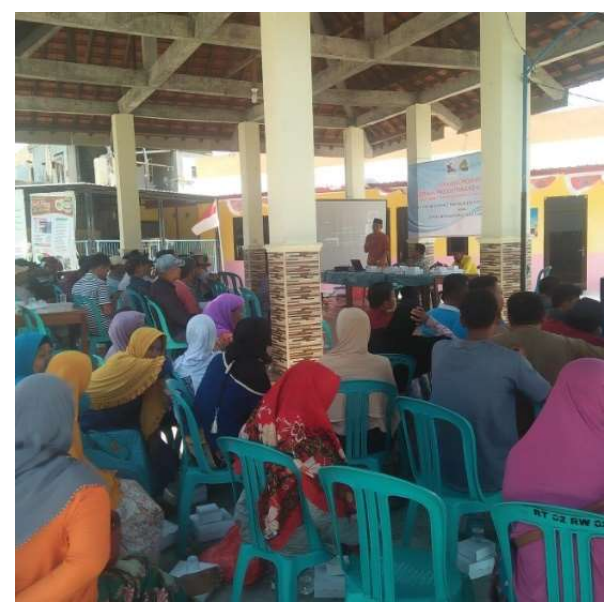

Gambar 4. Sosialisasi dan pelatihan pembuatan pelet ikan apung

\section{\% Evaluasi Peserta}

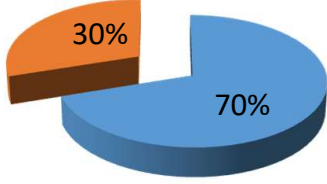

bisa buat

tdk bisa

Gambar 5 Diagram ketercapaian materi pelatihan.

\section{\% Kemampuan Memahami Materi Pelatihan}

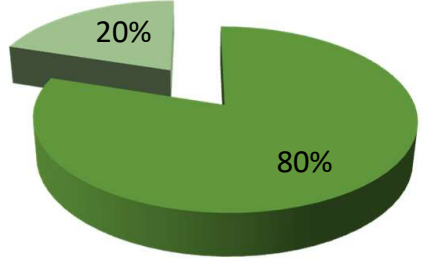

Memahami

kurang faham

Gambar 6 Diagram kemampuan skill masyarakat dalam membuat pelet.

Model implementasi pelatihan di masyarakat ini menggunakan pendekatan partisipasi yang mengarah pada kesadaran dan keterampilan masyarakat (Dewi 2014). Kegiatan pelatihan dan sosialisasi ini juga dihadiri oleh Dinas Perikanan Kabupaten Gresik. Pelatihan 
pembuatan pelet ikan ini sesuai dengan grand project yang digalakkan oleh Dinas Perikanan Kabupaten Gresik.

Adanya kesesuaian program ini dapat digunakan sebagai sinergi yang positif antara masyarakat, tim Universitas Islam Darul 'Ulum Lamongan, dan Dinas Perikanan Kabupaten Gresik. Selain pelatihan, dukungan peralatan juga diberikan oleh tim Universitas Islam Darul 'Ulum Lamongan. Bantuan alat berupa mesin pencetak pelet, Steamer, baskom, blender, pengaduk, ember, terpal, dan mesin press diberikan pada kelompok petani tambak di Desa Dahan Rejo untuk mendukung pembuatan pakan mandiri. Peralatan ini dapat digunakan secara berkelompok dan umum sesuai dengan peraturan dari kelompok petani tambak. Pelatihan kedua adalah mengenai pengemasan, pemasaran, dan manajemen usaha. Pelatihan kedua ini bertujuan untuk memberikan pengetahuan dalam membuat usaha baru disamping budidaya ikan. Pembuatan usaha baru dibidang pakan alternatif juga merupakan peluang usaha yang menjanjikan. Masyarakat menyambut dengan antusias dan termotivasi dalam mengembangkan home industri pelet ikan apung. Kegiatan ini juga didukung oleh Dinas Perikanan Kabupaten Gresik terkait bantuan permodalan dan sistem manajemen

\subsection{Pendampingan Program}

Pendampingan program dilakukan selama dua bulan. Pendampingan ini dilakukan dua minggu sekali. Kendala yang ditemukan di lapangan adalah: 1) Cuaca yang tidak menentu; 2) Ketersediaan bahan pendukung pelet; dan 3) Pemasaran dan pengenalan produk. Cuaca yang tidak menentu mengakibatkan pengeringan pelet yang kurang optimal. Pelet setelah digiling, dalam kondisi normal memerlukan waktu pengeringan 2 sampai3 hari. Sedangkan jika cuaca hujan, maka memerlukan waktu 4 - 6 hari. Hal ini menyulitkan petani tambak dalam mendapatkan pelet yang kering sempurna dan dapat terapung.

Solusi dari permasalah ini adalah pengeringan dilakukan seoptimal mungkin di dalam rumah dengan tempat yang luas, penerangan cukup, dan ventilasi cukup. Hal ini cukup membantu mengatasi kendala dari faktor cuaca. Kendala yang kedua adalah ketersediaan bahan pendukung, bahan pendukung yang agak sulit didapatkan adalah tepung ikan. Solusi dari kendala ini adalah dengan menggunakan ikan yang sudah tidak layak konsumsi, dikeringkan dan dibuat tepung secara mandiri. Selain itu, petani tambak juga membuat kesepakatan dengan penjual ikan untuk menggunakan limbah ikan sebagai bahan campuran pelet. Pengenalan dan pemasaran produk merupakan aspek diversifikasi. Tujuan inti pembuatan pelet ikan berbahan baku lokal adalah untuk pemenuhan pakan mandiri petani tambak, namun seiring berjalannya waktu, kelompok petani tambak mengembangkan menjadi unit usaha baru pembuatan pakan untuk dijual dan dipasarkan. Sebagai bentuk home indutri baru, maka proses pengenalan dan pemasaran menjadi kendala. Masyarakat luas belum banyak yang tahu tentang produk pelet alternatif dari bahan lokal yang dijual oleh petani tambak Desa Dahan Rejo. Hal ini harus dibantu dalam upaya pemasaran produk. Salah satu upayanya adalah dengan mengenalkan pada petani tambak lain di luar Desa Dahan Rejo, kios pakan lele, dan dipamerkan dalam berbagai kegiatan yang menarik. 
ISSN : $2620-4665$ (print)

ISSN : 2620 - 4673 (online)

Website : http://jurnal.untan.ac.id/index.php/JPLP2KM

\subsection{Monitoring dan Evaluasi}

Monitoring dan evaluasi secara kontinu dilakukan bersamaan dengan pendampingan program. Monitoring dan evaluasi dilakukan selama 2 bulan setiap 2 minggu sekali. Monitoring dilakukan dengan memerhatikan temuan di lapangan terkait kendala dan keberlanjutan program. Hasil monitoring akan dievaluasi untuk mendapatkan hasil perbaikan dan rencana tahap selanjutnya. Hasil monitoring dan evaluasi selain digunakan oleh tim sebagai proses pengembangan, juga digunakan oleh Dinas dan Perikanan Kabupaten Gresik untuk menyukseskan grand project di tahun ini. Evaluasi program secara umum menunjukkan bahwa kelompok petani tambak desa Dahan Rejo mampu membuat pelet ikan dari bahan lokal secara mandiri. Kelompok petani tambak juga berkomitmen untuk terus melakukan usaha budidaya ikan dan melanjutkan usaha baru, yaitu pembuatan pelet alternatif dari bahan lokal untuk dipasarkan dan dikelola secara profesional menjadi home industri yang potensial.

Dukungan dari berbagai pihak seperti Universitas Islam Darul 'Ulum Lamongan, koperasi, dan Dinas Perikanan Kabupaten Gresik juga akan terus dilakukan dan digalakkan dan membuka peluang juga untuk instansi lain yang dapat mendukung program ini.

\section{SIMPULAN DAN REKOMENDASI}

\section{SIMPULAN}

Simpulan dari program pemberdayaan masyarakat ini adalah masyarakat Desa Dahan Rejo mampu membuat pakan ikan apung dari bahan baku lokal secara teori dan praktik sehingga dapat digunakan sebagai solusi mahalnya harga pakan ikan dipasaran dan dapat menekan biaya produksi dalam usaha budidaya ikan. Kelompok petani tambak Desa Dahan Rejo berkomitmen untuk terus mengembangkan pembuatan pelet ikan sebagai upaya keberlanjutan program.

\section{REKOMENDASI}

Keberhasilan produksi pellet ikan apung ini dapat ditingkatkan secara massal dan dikomersilkan sehingga dapat nilai tambah penghasilan bagi kelompok petani tambak

\section{UCAPAN TERIMAKASIH}

Ucapan terimakasih disampaikan Direktorat Riset dan Pengembangan, Kemristekdikti melalui Program Diseminasi Produk Teknologi ke Masyarakat yang telah memberikan pendanaan.

\section{DAFTAR PUSTAKA}

Avianta D. 1998. Jurus Ampuh Anti Gagal Pembudidayaan Ikan Lele. Semarang (ID): Cipta karya Press. 
Boer I, Adelina, Pamukas NK. 2014. Pemanfaatan Fermentasi Ampas Tahu Dalam Pakan Ikan Untuk Pertumbuhan Ikan Gurami Osphronemus Gourame Lac. Dalam: Prosiding Seminar Antarabangsa ke 2, Ekologi, Habitat Manusia dan Perubahan Persekitaran. Riau (ID): Universitas Riau.

Darman S, Zakaria FR, Muhandri T. 2015. Studi Kelayakan Pendirian usaha kecil pakan ikan di Calingcing-Cianjur. Jurnal Manajemen IKM:Jurnal Manajemen Pengembangan Industri Kecil Menengah. 10(1): 1 - 8.

Darmansyah A, Sulistiono, Nugroho T, Supriyono E. 2016. Pemberdayaan Masyarakat melalui Pengembangan Budidaya Ikan Lele di Desa Balongan, Indramayu, Jawa Barat. Agrokreatif Jurnal IImiah Pengabdian Masyarakat. 2(1): 8 - 16.

Ekawati AW, Maimunah Y. 2009. Teknologi Pembuatan Pakan dengan Bahan Lokal untuk Meningkatkan Pendapatan Pembudidaya Lele Dumbo (Clarias Gareipinus) di Kota Probolinggo. Malang (ID): Universitas Brawijaya.

Hanif, Nurdin, Mawardi I. 2014. Pengabdian Bagi Petani Ikan Bandeng Desa Jambo Timu Pemkot Lhokseumawe yang Menghadapi Masalah Tingginya Harga Pakan. Dalam: Prosiding Seminar Nasional Penelitian dan PKM Sains, Teknologi dan Kesehatan. Halaman: 299 - 306.

Kurniawan, A., dan Lestiardi, RA. 2017. Induksi Mesin Pellet Ikan Untuk Meningkatkan Kegiatan Pakan Komunitas Pembudidaya Lele di Kabupaten Mojokerto. Journal of Innovation and Applied Technology. 3 (1) : 433-438

Lestari SF, Yuniarti S, Abidin Z. 2013. Pengaruh Formulasi Pakan Berbahan Baku Tepung Ikan, Tepung Jagung, Dedak Halus dan Ampas Tahu Terhadap Pertumbuhan Ikan Nila (Oreochromis Sp). Jurnal Kelautan. 6(1): 36 - 46.

Nasution EZ. 2006. Studi Pembuatan Pakan Ikan dari Campuran Ampas Tahu, Ampas Ikan, Darah Sapi Potong, dan Daun Keladi yang Disesuaikan dengan Standar Mutu Pakan Ikan. Jurnal Sains Kimia. 10 (1): 40 - 55.

Sukowardojo, B., Setiyono, dan Kustanto, MN. 2014. IbM Pengembangan Budidaya Azola Sebagai Upaya Peningkatan Mutu Pakan Ikan Dengan Penerapan Mesin Pencampur Pembuat Pellet. Laporan Akhir. Universitas Jember

Yulistiana YG, Rahayu I, Jannah RN, Setiyowati N, Maladina MR. 2016. Analisis Marketing Mix Pembuatan Pelet Ikan Alternatif dari Ampas Tahu di Desa Wakah Kecamatan Ngrambe Kapupaten Ngawi. Dalam: Seminar Nasional Program Studi Peternakan, UNS Surakarta (ID). 